\title{
Modeling the response of glacier systems to climate warming in China
}

\author{
XIE Zi-Chu, ${ }^{1,3}$ WANG Xin, ${ }^{2,3}$ FENG Qing-Hua, ${ }^{1}$ KANG Er'si, ${ }^{3}$ \\ LIU Chao-Hai, ${ }^{3}$ LI Qiao-Yuan ${ }^{1}$ \\ ${ }^{1}$ Institute of Resources and Environment, Hunan Normal University, Changsha 410081, China \\ E-mail:xiezc@hunnu.edu.cn \\ ${ }^{2}$ Research Institute of Geospatial Information Science, Hunan University of Science and Technology, Xiangtan 411201, China \\ ${ }^{3}$ Cold and Arid Regions Environmental and Engineering Research Institute, Chinese Academy of Sciences, \\ 260 Donggang West Road, Lanzhou 730000, China
}

\begin{abstract}
A glacier system is regarded as the ensemble of many glaciers sharing the same region, influenced by a similar climate and organized by certain intrinsic laws. It can be either 'sensitive' or 'steady'. On the basis of the structure of the glacier system and the nature of the equilibrium-line altitudes at the steady state, functional models of a glacier system responding to climate warming were established, using the Kotlyakov-Krenke equation relating annual glacier ablation and mean summer temperature and the glacier system's median size. The modeling results under the climatic scenarios with a rate of temperature increase of $0.01,0.03$ and $0.05 \mathrm{Ka}^{-1}$ indicate that by the end of this century the glacial area of China will be reduced by $-14 \%,-40 \%$ and $-60 \%$ respectively. However, model results show distinct differences between the sensitive glacier system and the steady glacier system.
\end{abstract}

\section{INTRODUCTION}

A glacier system is regarded as the ensemble of many glaciers sharing the same region, influenced by a similar climate and organized by certain intrinsic laws; it can be divided and subdivided based on certain characteristics (e.g. mountain massif, watershed boundaries) (Kotlyakov and Smolyarova, 1990). There are $59406 \mathrm{~km}^{2}$ of glacial area and $5590 \mathrm{~km}^{3}$ of glacial volume in China (C. Liu and others, 2000). Glaciers are a vital fresh-water resource in the arid western area of China. The recent temperature rise is the key factor in the variation of glaciers, which have been retreating since the middle of the last century due to global warming (Liu and others, 1999). As a result, many studies were carried out on the variation of glacier response to global warming (Kotlyakov and others, 1991, 2000; Shi and Liu, 2000; Ye and others, 2003).

The model of glacier system response to climate warming was previously applied on the glacierized regions of southern Tibet (Xie and others, 2002). In this paper, we improve our model further and apply it to glacier systems all over China and try to gain average results of glacier systems in China responding to climate warming during this century.

Table 1. Parameters of glacier systems in China for prediction

\begin{tabular}{lccccccc}
\hline $\begin{array}{l}\text { Glacier } \\
\text { systems }\end{array}$ & $S_{0}$ & $V_{0}$ & $S_{\text {med }}$ & $\mathrm{ELA}_{0}$ & $\mathrm{AAR}_{0}$ & $t_{\mathrm{s}}$ & $\mathrm{a}_{0}$ \\
& $\mathrm{~km}^{2}$ & $\mathrm{~km}^{3}$ & $\mathrm{~km}^{2}$ & $\mathrm{~m}$ & & ${ }^{\circ} \mathrm{C}$ & $\mathrm{mm}$ \\
\hline $\begin{array}{l}\text { Sensitive } \\
\text { Steady }\end{array}$ & 20923 & 1690 & 1.36 & 4794 & 0.65 & 2.63 & 1619 \\
& 38477 & 3903 & 8.74 & 5275 & 0.75 & -1.24 & 596
\end{tabular}

Notes: $S_{0}$ and $V_{0}$ : glacier area and volume; $S_{\text {med }}$ : median size; ELA equilibrium-line attitude during steady state; $\mathrm{AAR}_{0}$ : accumulation-area ratio; $t_{s}$ : mean summer temperature near $\mathrm{ELA}_{0} ; a_{0}$ : annual ablation.

\section{PARAMETERS FOR MODELS}

Glacier data (number, area, volume, etc.) were obtained from Chinese glacier inventories acquired from aerial surveys during the 1960s-80s. Glaciers were divided into 'sensitive' and 'steady' glacier systems (Fig. 1) based on the glacier system's mean summer temperature near the equilibrium-line altitude (ELA) and their median size. Temperature data were taken from the Climatic Atlas of Tibetan Plateau Climate which reflects meteorological conditions of the 1960s and 1970s. The parameters needed in order to run glacier system modeling are listed in Table 1.

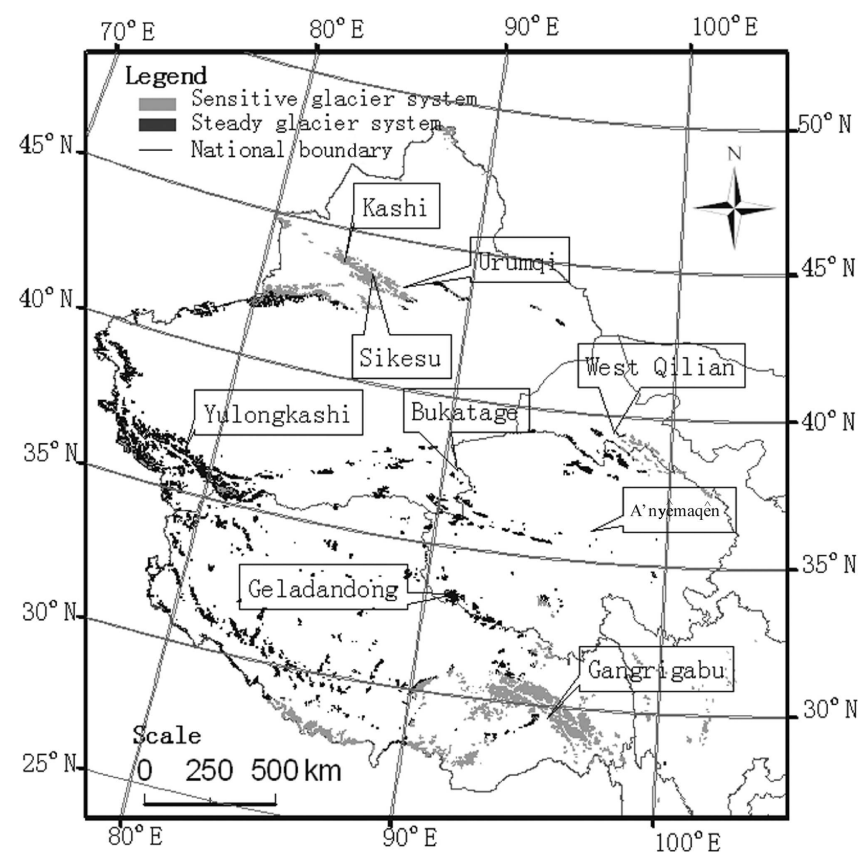

Fig. 1. Location and sensitivity to climate change of glaciers in China. 

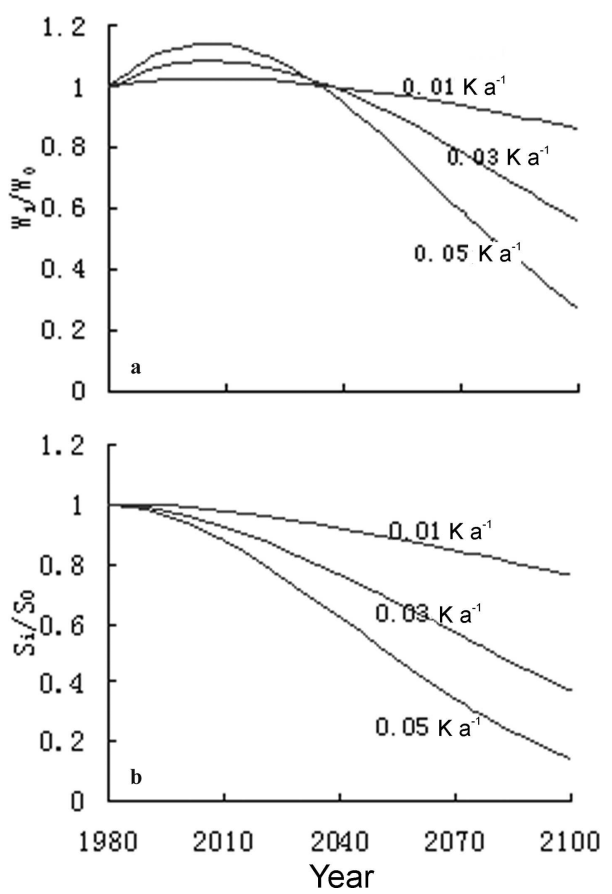

Fig. 2. Responses of a sensitive glacier system in China with respect to total runoff and glacier area in response to possible climatic scenarios in this century: (a) glacier runoff variation; and (b) glacier area variation.

\section{MODELING}

\section{Calculation of mass-balance change}

The specific net mass balance near $\mathrm{ELA}_{0}$ is approximately equal to the average net mass balance of a glacier (Xie and others, 1996), and the depth of ablation and runoff are also approximately equal to their corresponding average values (Kang and others, 1994). These laws can also be applied to glacier systems (Xie and others, 2002). With a given temperature rise, employing the ablation formula by Kotlyakov and Krenke (1982), the net balance of a glacier system, $b_{\mathrm{n} i}$ in a given year $i$ can be expressed as:

$$
\begin{aligned}
b_{\mathrm{n} i} & =a_{0}-a_{i} \\
& =1.33\left[\left(9.66+t_{\mathrm{s} 0}\right)^{2.85}-\left(9.66+t_{\mathrm{s} 0}+\Delta t_{\mathrm{si}}\right)^{2.85}\right],
\end{aligned}
$$

where $a_{0}$ and $a_{i}$ are ablation in the original year and in the given year $i, t_{\mathrm{s} 0}$ is the mean summer temperature near $\mathrm{ELA}_{0}$ in the original year and $\Delta t_{\mathrm{s} i}$ is the increase of mean summer temperature in the given year $i$.

We define the ratio between $\left|b_{n i}\right|$ and $a_{0}$ of a glacier system in the year $i$ as:

$$
\alpha_{i}=\frac{\left|b_{\mathrm{n} i}\right|}{a_{0}} .
$$

\section{Calculation of glacier runoff and area change for climate warming}

When temperature rises, glacier melting will accelerate, negative mass balance will occur, and therefore glacier runoff will increase. On the other hand, glacier area will decrease as glaciers retreat, and the total glacier runoff, $w_{i}$ in a given year $i$ will be:

$$
w_{i}=\left(r_{0}+r_{\mathrm{d} i}\right)\left(s_{0}-s_{\mathrm{d} i}\right),
$$

where $r_{0}$ and $s_{0}$ are the depth of runoff and area of glacier in the original year, respectively, and $r_{\mathrm{d} i}$ and $s_{\mathrm{d} i}$ are the increase
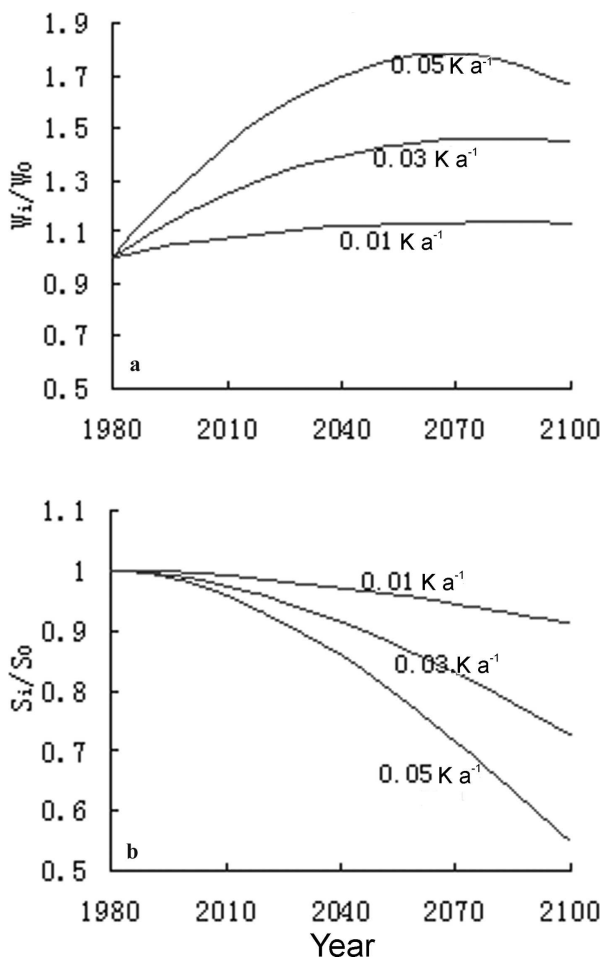

Fig. 3. Same as Figure 2, but for a steady glacier system.

of runoff depth and the decrease of glacier area due to climate warming in a given year $i$, respectively. With the temperature continuously rising, glacier runoff will first increase due to the increase in ablation, and after reaching its maximum amount, it will decrease again because of the reduction in glacier area. When it returns to the original amount of glacial runoff, we call this 'restoring original glacier runoff state' (Xie and Feng, 1996). At that time, ignoring evaporation, we can set $r_{0}=a_{0}, r_{\mathrm{d} i}=\left|b_{\mathrm{n} i}\right|$ and the decrease of glacier area, $s_{\mathrm{d} i}$, is:

$$
s_{\mathrm{d} i}=\frac{s_{0} \alpha_{i}}{\alpha_{i}+1} .
$$

We employ the widely used empirical formula to relate glacier area and thickness (Liu and Ding, 1986) to determine the time when a glacier reaches restoring original glacier runoff state under continuous warming, $T_{\mathrm{e} i}$ (Xie and Feng, 1996). Then the glacier area $s_{i}$ in a given year $i$ is:

$$
s_{i}=s_{i-1}-\frac{s_{\mathrm{d} i}}{T_{\mathrm{e} i}}=s_{i-1}\left[1-\frac{\alpha_{i}}{\left(\alpha_{i}+1\right) T_{\mathrm{e} i}}\right] .
$$

When it comes to predicting the variation in the glacier system, we use $s_{\text {med }}$ to replace the total area of the whole glacier system, $S$, and apply the laws mentioned above to arrive at the results. Ignoring evaporation, the total runoff of the glacier system, $W_{i}$, in a given year $i$ is:

$$
W_{i}=\frac{a_{i} S_{i}}{10^{6}}
$$

where $S_{i}$ is the total area of the glacier system in a given year $i$, and the constant $10^{6}$ is used to convert mm into $\mathrm{km}$.

\section{PREDICTION RESULTS}

The global mean surface air temperature will rise this century (Houghton and others, 2001) and so will the 
Table 2. Verification of model results with data of the glacier changes in western China in recent decades

\begin{tabular}{|c|c|c|c|c|c|c|}
\hline \multirow{3}{*}{$\begin{array}{l}\text { Location of } \\
\text { glacier systems }\end{array}$} & \multicolumn{3}{|c|}{ Survey data } & \multicolumn{3}{|c|}{ Model results } \\
\hline & \multirow[t]{2}{*}{ Period } & \multirow{2}{*}{$\begin{array}{c}\text { Retreat rate } \\
\text { \% }\end{array}$} & \multirow[t]{2}{*}{ Source } & \multirow{2}{*}{$\begin{array}{l}\text { Rate of air-temperature } \\
\text { increase } \\
\mathrm{Ka}^{-1}\end{array}$} & \multirow{2}{*}{$\begin{array}{l}\text { Period } \\
\text { years }\end{array}$} & \multirow{2}{*}{$\begin{array}{c}\text { Retreat rate } \\
\%\end{array}$} \\
\hline & & & & & & \\
\hline Ürümqi & 1964-92 & 13.8 & Chen and others (1996) & 0.05 & 30 & 13.4 \\
\hline Sikeshu & $1962-90$ & 2.6 & Liu and others (1999) & 0.03 & 27 & 3.1 \\
\hline West Qilian & 1956-90 & 10.3 & Liu and others (2002b) & 0.03 & 45 & 10.1 \\
\hline Hashi & $1962-89$ & 3.5 & S. Liu and others (2000) & 0.02 & 27 & 3.3 \\
\hline Bukatage & $1973-94$ & 1.6 & Li and others (1999) & 0.02 & 20 & 1.7 \\
\hline Geladandong & 1969-2000 & 1.7 & Lu and others (2002) & 0.02 & 31 & 1.7 \\
\hline A'nyêmaqên & 1966-2000 & 17.0 & Liu and others (2002a) & 0.05 & 60 & 16.5 \\
\hline Gangrigabu & 1980-2001 & 2.8 & Liu and others (2005) & 0.03 & 20 & 2.9 \\
\hline
\end{tabular}

temperature in northwestern China and on the Tibetan Plateau (Zhao and others, 2002). Since the prediction for a climatic warming trend is accompanied by uncertainties, we have made some assumptions about climatic scenarios with possible rates of temperature increase of $0.01,0.03$ and $0.05 \mathrm{~K} \mathrm{a}^{-1}$ in this century. We take 1980 as the original year and calculate the tendency of glacier systems' variations in response to these possible climatic scenarios. By the end of this century, the glacier area of China $(\Delta S / S)$ will on average be reduced by $14.2 \%, 39.7 \%$ and $59.7 \%$ under the climatic scenarios of $0.01,0.03$ and $0.05 \mathrm{~K} \mathrm{a}^{-1}$, respectively. However, there are distinct differences between the sensitive glacier system (Fig. 2) and the steady glacier system (Fig. 3).

\section{VERIFICATION AND DISCUSSION}

The continuous increase in the abundance of glacier variation observations and alpine meteorological data makes it possible to verify our models. However, care needs to be taken since there exists a lag time in glaciers' response to climate change, especially for large, thick debris-covered glaciers. But with respect to alpine glacier systems, the small and non-debris-covered glaciers which are sensitive to climate change are most prevalent in China, so we argue that our model is reliable. On the other hand, precipitation has been increasing in northwest China since the 1980s (Shi and others, 2003); but considering that the prediction of precipitation variation is accompanied by large uncertainties, we discuss the influence of precipitation on glacier systems under climate warming separately. The survey data for contemporary glacier variations (Fig. 1) and corresponding model results are compared in Table 2.

In the Northern Hemisphere, average air temperatures were $0.4 \mathrm{~K}$ higher in the 1980s than in the 1960s (Lin and Zhao, 1998). In Tibet the average rate of increase in air temperature was $>0.02 \mathrm{Ka}^{-1}$ (Kang, 1996) and it has been accelerating since the mid-1980s (Shi and others, 2002). On average, air temperatures were $0.5 \mathrm{~K}$ higher during 1985 2001 compared to $1958-85$ in the glacierized source region of the Ürümqi river (Li and others, 2003), with air temperatures increasing by $0.03 \mathrm{~K} \mathrm{a}^{-1}$ from 1985 to 2001 . Thus, the rate of air-temperature increase was on average 0.02$0.03 \mathrm{~K} \mathrm{a}^{-1}$ for the last $30-40$ years in the glacierized region of China. The survey data for glacier variations largely reflect this temperature increase, and they agree well with the results of our model under similar temperature-rise scenarios (Ürümqi and A'nyêmaqên were exceptions). Thus, we suggest that our model is generally reliable.

\section{ACKNOWLEDGEMENT}

This research project was supported by grants from the National Natural Science Foundation of China (40371027).

\section{REFERENCES}

Chen, J., C. Liu and M. Jin. 1996. Application of the repeated aerial photogrammetry to monitoring glacier variation in the drainage area of the Ürümqi River. J. Glaciol. Geocryol., 18(4), 331-336. [In Chinese with English summary.]

Houghton, J.T. and 7 others. 2001. Climate change 2001: the scientific basis. Contribution of Working Group I to the Third Assessment Report of the Intergovernmental Panel on Climate Change. Cambridge, etc., Cambridge University Press.

Kang, E., C. Liu, C. Wang, T. Han and W. Zhang. 1994. Seasonal variation of mass balance and altitude dependency of total melt in the glacierized source area of the Ürümqi River. J. Glaciol. Geocryol., 16(2), 119-127. [In Chinese with English summary.]

Kang, X. 1996. The features of climate changes in the Qingzang Plateau area during the last 40 years. J. Glaciol. Geocryol., 18, 281-288.

Kotlyakov, V.M. and A.N.Krenke. 1982. Investigations of the hydrological conditions of alpine regions by glaciological methods. IAHS Publ. 138 (Symposium at Exeter 1982 Hydrological Aspects of Alpine and High Mountain Areas), $31-42$.

Kotlyakov, V.M. and I.M. Lebedeva. 2000. Possible change of glacier and runoff in the highest Asian mountains in the context of global climate warming. Mater. Glyatsiol. Issled. 88, 3-15. [In Russian.]

Kotlyakov, V.M. and N.A. Smolyarova. 1990. Elsevier's dictionary of glaciology: in English, Russian, French and German. Amsterdam, etc., Elsevier.

Kotlyakov, V.M., M.G. Grosswald, M.B. Dyurgerov and V.L. Mazo. 1991. Reaktsiya oledeneniya na predstoyashchiye izmeneniya klimata [The reaction of glaciers to impending climatic change]. Polar Geog. Geol., 15(3), 203-217.

Li, Z., W. Sun and Q. Zeng. 1999. Deriving glacier change information on the Xizang (Tibetan) plateau by integrating RS and GIS techniques. Acta Geogr. Sin., 54(3), 263-268. [In Chinese.l 
Li, Z., T. Han, Z. Jing, H. Yang and K. Jiao. 2003. A summary of 40-year observed variation facts of climate and Glacier No. 1 at headwaters of Ürümqi River, Tianshan, China. J. Glaciol. Geocryol., 25(2), 117-123. [In Chinese with English abstract.]

Lin, Z.Y. and X. Zhao. 1998. Climatic change in Qinghai-Xizang (Tibetan) Plateau and its comparison with nearby area, Antarctic and Arctic. In Tang, M., G. Cheng and Z. Lin, eds. Contemporary climatic variations over the Qinghai-Xizang (Tibet) Plateau and their influences on environments. Guangzhou, Guangdong Science and Technology Press, 145-160. [In Chinese.]

Liu, C. and L. Ding. 1986. Some comments on the glacier inventory of $\mathrm{I} / \mathrm{i}$ river drainage basin in Tian Shan Mountains. In Ding, L., W. Xie and C. Liu, eds. Glacier inventory of China. Beijing, Science Press, 1-6. [In Chinese.]

Liu, C., E. Kang and S. Liu. 1999. Study on glacier variation and its runoff responses in the arid region of Northwest China. Sci. China D, 42, 55-62.

Liu, C., Y. Shi, Z. Wang and Z. Xie. 2000. Glacier resources and their distributive characteristics in China: a review of the Chinese glacier inventory. J. Glaciol. Geocryol., 22(2), 106112. [In Chinese with English summary.]

Liu, S., Z. Xie and C. Liu. 2000. Mass balance and fluctuations of glaciers. In Y. Shi, M. Huang, T. Yao and Y. Deng. Glaciers and their environments in China: the present, past and future. Beijing, Science Press, 101-131. [In Chinese.]

Liu, S., A. Lu, Y. Ding, T. Yao, L. Ding, G.Li and R.Le.B. Hooke. 2002a. Glacier fluctuations and inferred climate changes in the A'nyêmaqên Mountains in the source area of the Yellow River. J. Glaciol. Geocryol., 24(6), 701-707.

Liu, S., Y. Shen, W. Sun and G. Li. 2002b. Glacier variation since the maximum of the Little Ice Age in the western Qilian Mountains, northwest China. J. Glaciol. Geocryol., 24(3), 227233. [In Chinese with English abstract.]
Liu, S. and 7 others. 2005. Glacier changes since the early 20th century in the Gangrigabu Mountains, Southeast Tibetan Plateau. J. Glaciol. Geocryol., 27(1), 55-63. [In Chinese.]

Lu, A., T. Yao, S. Liu, L. Ding and G. Li. 2002. Glacier change in the Geladandong area of the Tibetan Plateau monitored by remote sensing. J. Glaciol. Geocryol., 24(5), 559-562.

Shangguan, D., S. Liu, Y. Ding, L. Ding and G. Li. 2004. Glacier changes at the head of Yurungkax River in the West Kunlun Mountains in the past 32 years. Acta Geogr. Sin., 59(6), 855862. [In Chinese with English abstract.]

Shi, Y. and S. Liu. 2000. Estimation of the response of glaciers in China to the global warming in the 21 st century. Chinese Sci. Bull., 45(7), 668-672. [In Chinese.]

Shi, Y., Y. Shen and R. Hu. 2002. Preliminary study on signal, impact and foreground of climatic shift from warm-dry to warmhumid in northwest China. J. Glaciol. Geocryol., 24(3), 219226. [In Chinese with English abstract.]

Xie, Z. and Q. Feng. 1996. The influence of glacier fluctuation on glacier runoff in High Asia. In Proceedings of the Fifth Chinese Conference on Glaciology and Geocryology, vol. 1. Lanzhou, Gansu Culture Press, 454-461. [In Chinese with English abstract.]

Xie, Z., L. Ding, C. Liu and S. Liu. 1996. Mass balance at the steady state equilibrium line altitude and its application. J. Glaciol. Geocryol., 18(1), 1-9. [In Chinese with English summary.]

Xie, Z., Q. Feng and C. Liu. 2002. Modeling the variation of glacier system - taking the southern Tibet region as an example. J. Glaciol. Geocryol., 24(1), 16-27. [In Chinese with English abstract.]

Ye, B., Y. Ding, F. Liu and C. Liu. 2003. Responses of various-sized alpine glaciers and runoff to climatic change. J. Glaciol., 49(164), 1-8.

Zhao, Z., X. Gao, M. Tang and Y. Xu. 2002. Projections of climate change. In Qin, D. and Y. Ding, eds. Assessment on environment change in West China, vol. 2: projections of environment change in West China. Beijing, Science Press, 16-46. [In Chinese.] 